\title{
Leaf rot disease of cauliflower caused by Choanephora cucurbitarum in India
}

\author{
Robin Gogoi $^{1}$ - S. Kulanthaivel ${ }^{1}$ - S. N. Rai ${ }^{1}$ - D. B. Ahuja ${ }^{2}$
}

Received: 31 December 2014 / Accepted: 26 September 2016/Published online: 7 October 2016

(C) Australasian Plant Pathology Society Inc. 2016

\begin{abstract}
Leaf rot of cauliflower caused by Choanephora cucurbitarum is reported for the first time in India. Koch's postulates were fulfilled for the first time for this fungushost association demonstrating that $C$. cucurbitarum, known to be the pathogen behind soft rot on numerous hosts is also a pathogen of cauliflower.
\end{abstract}

Keywords Brassica oleracea · Mucorales · Soft rot · Vegetable diseases $\cdot$ Zygomycota

Choanephora cucurbitarum (Mucorales) is an important plant pathogen that causes soft rot of floral parts and fruits of many plants, including summer squash, pumpkin, pepper and okra (Agrios 1997). Cauliflower (Brassica oleracea) is an important crop in India and any diseases found on this host are of potential agricultural and economic relevance.

In September 2012, 2013 and 2014, leaves of an early variety of cauliflower (cv Early Kuary) bearing typical soft rot symptoms, accompanied by superficial fungal growth

Robin Gogoi

r.gogoi@rediffmail.com; rgogoi@iari.res.in

S. Kulanthaivel

kulanthai7@gmail.com

S. N. Rai

snraipath@gmail.com

D. B. Ahuja

deshbandhu4@rediffmail.com

1 Divisions of Plant Pathology, Indian Agricultural Research Institute, New Delhi 110 012, India

2 National Centre for Integrated Pest Management, Pusa Campus, New Delhi 110012, India were collected at Palarikhurd Village, Sonipat (28 59'26.53" $\mathrm{N} ; 7^{\circ} 00^{\prime} 57.30^{\prime \prime} \mathrm{E} ; 249 \mathrm{~m}$ a.s.1.), Haryana, India. Disease symptoms were observed and photographed in the field. Samples were taken for later examination in the laboratory. Fragments of infected leaves bearing pin head-like fungal growth were surface sterilized by dipping in $1 \%$ sodium hypochlorite for $1 \mathrm{~min}$ and rinsing once with sterilized distilled water and aseptically transferred to plates containing PDA (potato dextrose-agar) and left at room temperature for $48 \mathrm{~h}$. Homogeneous cultures were obtained and one was selected for further study and deposited in the Indian Type Culture Collection (ITCC 7521).

Slides were prepared by mounting a colony fragment in lactophenol. The fungal structures were observed under a microscope (Olympus, Magnus MLXi). The morphological and cultural characters of the fungus were recorded and compared with published descriptions of soft rot-fungi (Kwon et al. 2001; Kagiwada et al. 2010). Profuse and rapidly growing white mycelium was formed on PDA after $36 \mathrm{~h}$. Sporangiophores bearing apical sporangiola were formed. Sporangia were sub-globose $(35-85 \mu \mathrm{m}$ diam) and monosporus sporangiola were elliptic, fusiform or ovoid (8$13 \times 11-22 \mu \mathrm{m})($ Fig. 1c). Sporangiospores were elliptic, fusiform or ovoid (7-10.5 × 10-27 $\mu \mathrm{m})$, brown, with or without three or more thin appendages at both ends (Fig. 1d). This morphology is typical of $C$. cucurbitarum as described by Kwon et al. (2001) and Kagiwada et al. (2010).

Identity of the fungus involved on cauliflower leaf rot was further investigated by comparison of ITS and TEF sequences of ITCC 7521 with GenBank data (White et al. 1990).

Genomic DNA was extracted from the pure culture of C. cucurbitarum through the cetyl trimethyl ammonium bromide (CTAB) method with slight modifications (Karthikeyan et al. 2010). DNA extracted by adding chloroform: isoamyl alcohol in the ratio of $24: 1$ centrifuged at $12,000 \mathrm{rpm} / 10 \mathrm{~min}$ 
Fig. 1 Symptoms and signs of Choanephora rot on cauliflower and morphology of the causal agent Choanephora cucurbitarum a Symptom of leaf rot of cauliflower in field; $\mathbf{b}$ Numerous monosporus sporangiola (at $10 \times 100 \mathrm{X})$; Fusiform sporangiospores with appendages (at 10x100X); d Cauliflower seedlings showing typical symptoms of leaf and bud rotting

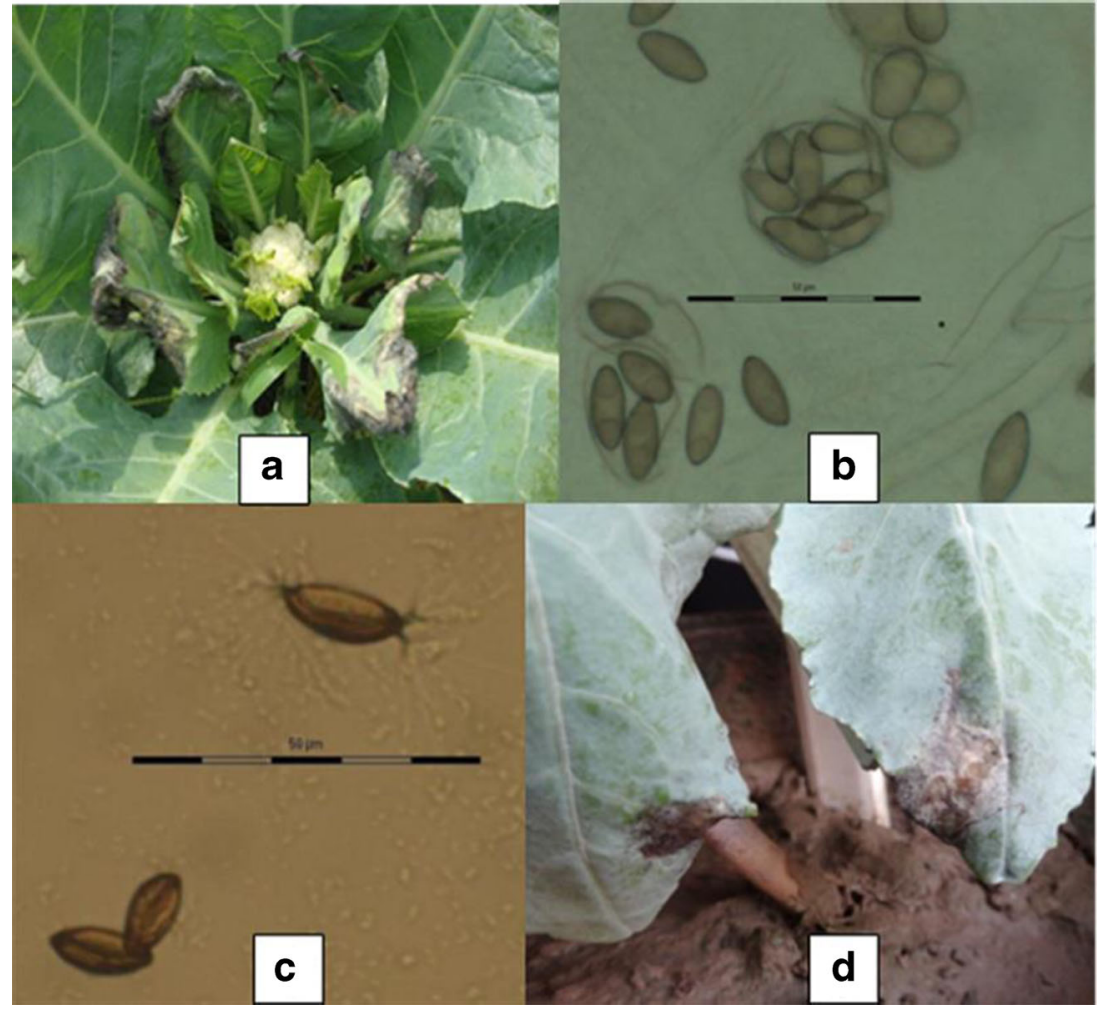

repeated this step twice, suspended with $150 \mu$ of TE buffer (10 mM Tris pH 8.0, 1 mM EDTA pH 8.0). RNA was digested by adding $2 \mu$ of RNAse $A$ and incubated at $37^{\circ} \mathrm{C}$ for $1 \mathrm{~h}$ and stored $-20{ }^{\circ} \mathrm{C}$ for further use.

The internal transcribed spacer (ITS) region was amplified with universal primers ITS1 and ITS4 (White et al. 1990). The reaction mixtures were prepared in a total volume of $100 \mu \mathrm{l}$ with a final concentration of $50 \mathrm{ng}$ DNA, $10 \mu \mathrm{l}$ of $10 \times$ assay buffer, $1.5 \mu \mathrm{MMgCl}_{2}, 10 \mu \mathrm{M}$ dNTP mix, $10 \mathrm{pM}$ of each primer, and 2.5 $\mathrm{U}$ of Taq DNA polymerase (Bangalore Genei, India) and the volume was made up to $100 \mu \mathrm{L}$ with sterile double distilled water. The PCR was performed with a PCR Thermal Cycler MP (Bioer, Japan) according to the following program sequence: initial denaturation $94{ }^{\circ} \mathrm{C}$ for $3 \mathrm{~min}$, followed by 35 cycles of $1 \mathrm{~min}$ at $94{ }^{\circ} \mathrm{C}, 30 \mathrm{~s}$ at $60{ }^{\circ} \mathrm{C}$ and $1 \mathrm{~min}$ at $72{ }^{\circ} \mathrm{C}$ with a final extension step for $3 \mathrm{~min}$ at $72^{\circ} \mathrm{C}$. After thermal cycling, the amplified product was run on a $1.2 \%$ agarose gel, stained with ethidium bromide, The gel was visualized under UV radiation in a gel documentation system (Biorad, USA) and digitally photographed (Canon, Tokyo, Japan).

Translation elongation factor (TEF) was amplified with specific primers EF1-645F and EF1-1190R (Fiers et al. 2011). The reaction mixture prepared to the total volume of $50 \mu \mathrm{l}$ with final concentration of $75 \mathrm{ng}$ of DNA, $5 \mu \mathrm{l}$ of $10 \mathrm{X}$ Taq buffer, $1.5 \mu \mathrm{M} \mathrm{MgCl} 2,8 \mu \mathrm{M}$ dNTP mix, $10 \mathrm{pM}$ of each primer, and 1.5 U of Taq DNA polymerase (Bangalore Genei, India) and the volume was made up to $50 \mu \mathrm{L}$ with sterile double distilled water. The PCR was performed with aPCR Thermal Cycler MP (Bioer, Japan) according to the following program sequence: initial denaturation $94{ }^{\circ} \mathrm{C}$ for $2 \mathrm{~min}$, followed by 30 cycles of $1 \mathrm{~min}$ at $94{ }^{\circ} \mathrm{C}, 30 \mathrm{~s}$ at $56^{\circ} \mathrm{C}$ and $1 \mathrm{~min}$ at $72{ }^{\circ} \mathrm{C}$ with a final extension step for $10 \mathrm{~min}$ at $72^{\circ} \mathrm{C}$. The amplified product was electrophoresed and digitally photographed as cited above.

The amplified products of ITS and TEF were partially sequenced at Amnion DNA sequencer (Bengaluru, India). The sequences were deposited in NCBI GenBank under the following accession numbers (for ITS - KJ817815, for TEFKM214205). A BLAST search in GenBank revealed $99 \%$ NT identity with C. cucurbitarum as per the comparison with the accession numbers KF724997 for ITS and AF157239.1 for TEF. Identity of the isolate ITCC 7521 was therefore confirmed as C. curbitarum.

Healthy seedling of cauliflower (cv Early Kuary) were planted individually in each of ten plastic pots containing containing sterilized sandy loam soil. When the plants were thirty days-old they were inoculated with $5 \mathrm{~mm}$ diam, sporulating culture discs obtained from 5 days old ITCC 7521 colonies formed on PDA. Discs were placed on leaf margins (two leaves/plant) and tender buds. The pots were then covered with an internally moistened plastic bag and kept inside an incubator (Ferrotek) adjusted to $25^{\circ} \mathrm{C}$. The plastic bags were removed after three days. As a control, PDA disks with no fungus were deposited on leaves of two separate plants and these were treated as described above. Typical soft rot 
symptoms appeared after 5 to 7 days of inoculation, firstly at the margins of younger leaves as water soaked areas, followed by inward rolling and rapid rotting of the infected leaves that became black (Fig. 1f). Later (7 days after inoculation) the infected areas were covered with pale greyish brown fungal colonies (Fig. 1g). This is the first record of C. cucurbitarum causing leaf rot of cauliflower in India and the first time the pathogenicity of this fungus to cauliflower was demonstrated.

\section{References}

Agrios GN (1997) Plant pathology. Academic Press, USA

Fiers M, Edel-Hermann V, Héraud C, Gautheron N, Chatot C, Le Hingrat

Y, Bouchek-Mechiche K, Steinberg C (2011) Genetic diversity of
Rhizoctonia solani associated with potato tubers in France. Mycologia 103:1230-1244

Kagiwada S, Kayano Y, Hoshi H, Kawanishi T, Oshima K, Hamamoto H, Horei H, Namba S (2010) First report of Choanephora rot of ice plant (Mesenbryanthemum crystallinum) caused by Choanephora cucurbitarum in Japan. J Gen Plant Pathol 76:345-347

Karthikeyan V, Patharajan S, Palani P, Spadaro D, Gullino ML, Garibaldi (2010) Modified simple protocol for efficient fungal DNA extraction highly suitable for PCR based methods. Global J Mol Sci 5:37-42

Kwon JH, Shen SS, Park CS (2001) Pod rot of cow pea (Vigna sinensis) caused by Choanephora cucurbitarum. Plant Pathol J 17:354-356

White TJ, Bruns T, Lee S, Taylor J (1990) Amplification and direct sequencing of fungal ribosomal RNA genes for phylogenetics. In PCR protocols: A guide to methods and applications, MA Innis, DH Gelfand, JJ Shinsky, TJ White (ed) Academic Press, San Diego 